\title{
Uma escola de governo em saúde
}

A Escola Nacional de Saúde Pública (ENSP) pretende, nos próximos anos, responder de modo propositivo às exigências de maior responsabilização e de ampliação da governança da política pública e das funções do Estado, um desafio contemporâneo às Escolas de Saúde Pública. Para responder a estas exigências, vamos construir uma Escola de Governo em Saúde na ENSP - uma das orientações estratégi cas para este próximo quadriênio. Uma Escola que prepare, mais do que administradores públicos, a verdadeira liderança nacional do setor saúde. Que seja capaz de compreender e organizar o enfrentamento dos verdadeiros determinantes da saúde, o que implica numa sempre falada e pouco praticada ação inter-setorial e na capacidade de construção de alianças com outros setores do aparelho de Estado e com a comunidade organizada.

Uma liderança cujo compromisso político tenha uma sólida base técnica. Que saiba manejar instrumentos novos, não apenas aqueles desenvolvidos historicamente pela saúde pública para a prevenção das doenças, o controle de riscos isolados ou a recuperação da saúde. Na realidade, estes últimos também necessitam de uma ampla renovação teórica e prática, pois tampouco tem respondido aos graves problemas nacionais no campo da saúde individual e coletiva. Renovados, devem ser incorporados a uma prática nova e maior, da promoção da saúde, que antecipa-se aos problemas, enfrentando os determinantes da saúde e não exclusivamente suas conseqüências, trabalhando, enfim, para a qualidade de vida.

Nossa Escola de Governo em Saúde quer também impregnar-se de cidadania. Quer identificar, acompanhar e incorporar ao seu acervo de casos as centenas de experiências bem sucedidas que os sistemas locais municipais de saúde, bem como organizações populares, sindicais e o movimento social em geral vem desenvolvendo em todo o país.

A natureza da iniciativa e as dimensões do país recomendam que a implementação de uma proposta desta envergadura se realize com a utilização de abordagens pedagógicas contemporâneas, como é o caso da educação à distância, com o uso intensivo da tecnologia da informação, bem como os estudos de caso, que ensinam a partir de experiências concretas bem sucedidas, entre outras opções metodológicas.

O programa de trabalho da ENSP como Escola de Governo em Saúde será construído em estreita parceira com atores relevantes do Sistema Único de Saúde, como o Ministério da Saúde, o CONASS, o CONASEMS e o Conselho Nacional de Saúde, assim como, com outros agentes técnicos e políticos, que devem ser considerados parceiros privilegiados na reorientação do papel da nossa instituição.

A criatividade é a base fundamental das instituições de ciência, como a nossa. Por isso, a orientação estratégica complementar à criação da Escola de Governo na ENSP se refere à pesquisa e a denominamos de gestão da diversi dade. Uma diversidade que vem sendo construída ao longo de dez anos de uma experiência muito bem sucedida de funcionamento da pós-graduação nesta Escola. Mais de 90 projetos de investigação estão em desenvolvimento no interior de cerca de 25 linhas de pesquisa institucional. Ano após ano, cerca de 20 doutores e 50 mestres em saúde pública são formados nesta instituição e suas teses e dissertações incorporadas ao acervo científico nacional e colocadas à disposição do sistema de saúde.

É fundamental garantir a difusão apropriada de toda esta produção científica da ENSP para o sistema de saúde, os pares acadêmi cos e a sociedade em geral. Para tanto, torna-se imprescindível a manutenção e o aperfeiçoamento dos Cadernos de Saúde Pública e do Radis, poderosos instrumentos de contacto desta Escola com a sociedade.

Numa palavra está a chave para a implementação desta proposta: parceria. Interna, com a coesão dos Departamentos e grupos de pesquisa em torno da redefinição do papel da ENSP frente ao sistema de saúde. E externa, com os usuários dos nossos produtos do conhecimento, transformados em ferramentas úteis para a capacidade de governança e o desenvolvimento da sociedade brasileira.

Paulo Marchiori Buss

Diretor da ENSP 


\section{A school of government in health}

In the coming years, The National School of Public Health (ENSP) intends to respond with proposals to meet the demands for greater responsibility in public policy governance and an expanded role by the state, one of the main challenges now faced by schools of public health. To meet such demands, we will establish a School of Government in Health within ENSP as a prime strategic goal for the next four years. Beyond public administrators, this School will train a veritable national leadership in the health sector, capable of comprehending and organizing the effort to deal with the true determinants of health both inside and outside the sector. This undertaking will entail the often-mentioned but rarely practiced issue of intersectorial action and the capacity to forge alliances with other sectors of government as well as the organized community.

Such a leadership necessarily involves a commitment with a solid technical base, capable of handling new tools beyond those traditionally utilized by public health to prevent disease, control isolated risk factors, and recover individual health. These traditional tools will also have to be renewed and incorporated into a new, broader practice, that of health promotion, seeking to anticipate problems by dealing with the determinants of health rather than merely the consequences of the lack thereof: in short, working to promote quality of life.

Our School of Government in Health is also intended to be ripe with citizenship, identifying, accompanying, and incorporating hundreds of successful experiments from local health systems into our own case series, along with those of grassroots and trade union organizations and the social movement in general from all over Brazil.

Both the nature of this initiative and Brazil's huge dimensions require that the implementation of such an ambitious proposal be founded on contemporary pedagogical approaches, like long-distance, computer-based learning and case studies that teach on the basis of successful experiences, in addition to other methodological options.

The work program at the School of Government in Health will be based on close partnership with relevant protagonists from the country's Unified Health System (SUS), such as the Ministry of Health, National Council of State Secretaries of Health, National Council of Municipal Secretaries of Health, and National Health Council, as well as other technical and political stakeholders, all prime partners in reorienting our institutional role.

Creativity is the cornerstone of scientific institutions such as ours. A complementary strategic guideline for creating the School of Government in Health will thus be research in what we call management of diversity. Such diversity has been established over the course of ten years of a successful experience in implementing and developing graduate studies in public health at ENSP. More than 90 research projects are currently under way in 25 lines of research within the institution. Every year some 20 Ph.D.'s and 50 Master's in Public Health are awarded by this institution, and the theses and dissertations are incorporated into the store of scientific knowledge made available to the country's health system.

It is crucial to adequately disseminate all of ENSP's scientific production to the health system, our academic peers, and society at large. To this end, it is indispensable to maintain and enhance Cadernos de Saúde Pública and RADIS, powerful tools for ENSP to maintain contact with society.

One word is the key to implementing this proposal: partnership. Internally, by bolstering the Departments and research groups in helping redefine the role of ENSP vis-à-vis the health system. Externally, with the users of the knowledge we create as products, turned into useful tools for the governance and development of Brazilian society.

Paulo Marchiori Buss

Director - ENSP 